\title{
Feasibility Study for Using Energy-Harvesting Floor in Urban Public Transportation System: Case of Subway Stations
}

\author{
Miguel Angel Saldaña Cabrera, Aida Huerta Barrientos* \\ Department of Systems Engineering, National Autonomous University of Mexico, Mexico City, Mexico.
}

\begin{abstract}
How to cite this paper: Miguel Ange Saldaña Cabrera, Aida Huerta Barrientos. (2020) Feasibility Study for Using Energy-Harvesting Floor in Urban Public Transportation System: Case of Subway Stations. Journal of Electrical Power \& Energy Systems, 4(1), 11-21.

DOI: 10.26855/jepes.2020.10.002
\end{abstract}

Received: September 14, 2020

Accepted: October 8, 2020

Published: October 16, 2020

*Corresponding author: Aida Huerta Barrientos, Department of Systems Engineering, National Autonomous University of Mexico, Mexico City, Mexico.

Email: aida.huerta@comunidad.unam.mx

\begin{abstract}
Over the past 50 years, human activity has released huge amounts of greenhouse gases, particularly because of their dependence on fossil fuels, causing global warming which in turn brings variations in the weather for long periods leading to climate change. In this direction, the adoption of renewable energy and the increase in the electric car fleet are presented as the promising solution of a more efficient and sustainable paradigm. The principal purpose of this paper is to develop a feasibility study for using energy-harvesting floor in urban public transportation system and to apply it to the case of Mexico City subway stations. First, we review the literature about the use of renewable energy in urban public transport system around the world as well as the best practices and the feasibility studies. Second, we propose a feasibility study for using energy-harvesting floor in urban public transport system. Third, we validate the feasibility study considering the case of a Mexico City subway station. Even though the adoption of technology based on renewable energy in Mexico is low due to the high investment required, the results of this study showed the benefits of using energy-harvesting floor in Mexico City subway stations. Such solution contributes mainly at the mitigation of $\mathrm{CO}_{2}$ level and the installation is ideal in urban context. We consider that the feasibility study proposed can support the decision-making process of Mexico City subway authorities.
\end{abstract}

\section{Keywords}

Energy-harvesting floor, Subway stations, Mexico City, Feasibility study

\section{Introduction}

Energy is a pillar of development, for this reason, energy enables investments, innovations, and new industries that support the growth of economy. Likewise, universal access to affordable, reliable and sustainable energy is part of the Sustainable Development Goal (SDG) 7, and is essential to achieve other SDGs, being the axis of efforts to confront climate change [1]. Nowadays, there is a great global trend regarding the situation and evolution of environmental impact; which causes climate change; however, mitigation progress is very slow.

The case of Mexico shows us a high demand in the energy sector in this country due to the rapid population 
growth (see Figure 1) and its needs to be satisfied [2, 3]. These needs are due to technological advances, mainly; since new devices require power [4]. Additionally, the recent transportation needs require more and more energy consumption. It is important to note that in Mexico, the transportation sector represents the $47 \%$ of the total energy consumption. For this reason, also the transportation is the main source of $\mathrm{CO}_{2}$ emissions in the Metropolitan Area of the Valley of Mexico, representing more than $60 \%$ of $\mathrm{CO}_{2}$ [5] (see Figure 2). Based on the 2030 Agenda of the United Nations (UN), Mexico has made an international commitment for reducing greenhouse gases, due to high $\mathrm{CO}_{2}$ emissions and their respective consequences on the environment and health. Considering this commitment, the use of renewable sources of energy, the technological adoptions in the energy sector and the sustainable transportation will be the main axes to face in the next decade.

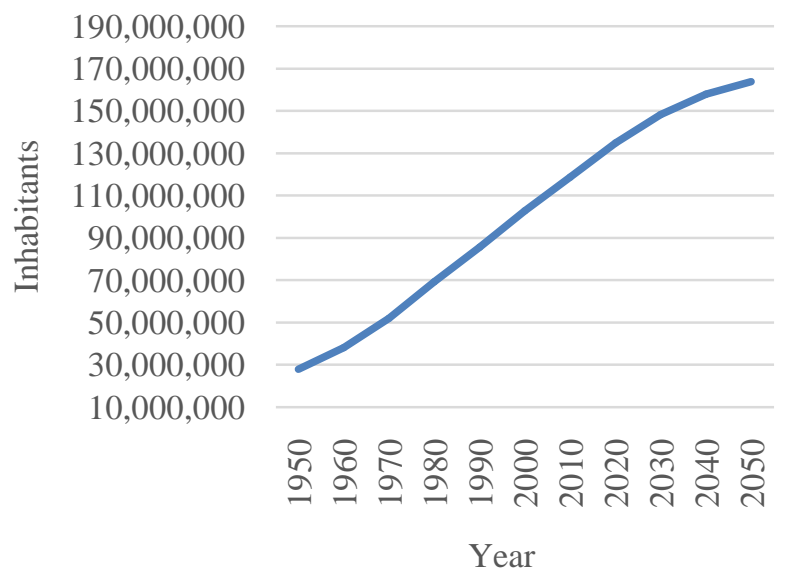

Figure 1. Mexican population growth from 1950 to 2050, the last 30 years are based on forecasting.

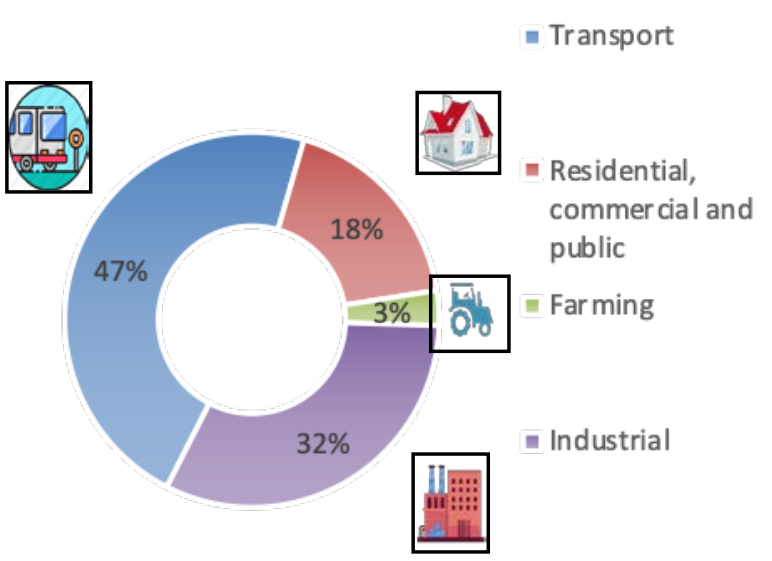

Figure 2. Distribution of energy demand by sector.

The urban mobility of the inhabitants of Mexico City is achieved through a public and private infrastructure of different transport systems. On the one hand, the public transport network includes thousands of buses, minibuses and collective vans; known as combis, public buses belonging to the local Government such as the M1 Mobility System and Metrobús, the Electric Transport Service (STECDMX) such as the Trolleybus, Light Train and Suburban Train, and the one of the most extensive subway networks in the world called the Collective Transportation System Metro (CTSM).

On the other hand, the private transportation is mainly private taxis which use mobile applications such as Uber, Didi, Easy Taxi, Cabify, etc. Regarding the case of the CTSM, 88\% of total energy consumption is used to energize the motors and $12 \%$ is allocated to public lighting and electromechanical stairs [6], generating approximately 
2.875,29 $\mathrm{tCO}_{2 \mathrm{e}}$ in 2018. Because the main sources of energy are through hydrocarbons, the CTSM is considered as one of the main causes of pollution in Mexico City, which causes an increase in greenhouse gases, which cause global warming and its consequences through climate change, which seriously affect all living beings.

The adoption of renewable energies for public transportation systems is mandatory and it probably would contribute to reduce greenhouse gases generated by the combustion of fossil sources that means mitigation of climate change. Also safe, affordable and sustainable transportation system could contribute to achieve the 2030 Sustainable Development Goals, as for example: goal 7 Affordable and clean energy, goal 11 Sustainable cities and communities and goal 13 Climate Action [7].

In this direction, the principal purpose of this paper is to develop a feasibility study for using energy-harvesting floor in urban public transportation system and to apply it to CTSM stations. We consider that the feasibility study proposed can support the decision-making process of Mexico City subway authorities.

The study is divided into four main sections. Firstly, we present a literature review about the use of renewable energy in urban public transport system around the world as well as well as the main examples of Energy-Harvesting Floor in Urban Public Transportation System. Secondly, we propose a feasibility study for using energy-harvesting floor in urban public transportation system. Thirdly, we validate the feasibility study considering the case of a CTSM station considering an agent-based simulation model. Finally, the concluding remarks are presented.

\section{Literature review}

\subsection{Using renewable energy in urban public transportation systems}

\subsubsection{Coradia iLint hydrogen train}

It is considered as the first officially registered hydrogen train that started operations on July 11, 2018, for collective transportation with the approval of the German Railways Authority (EBA) [8]. Coradia iLint is powered by a fuel cell that produces electricity through a combination of hydrogen and oxygen, which generates only steam and water emissions [9, 10]. In addition to the cells, it has a set of innovative elements, as excess energy is stored in lithium-ion batteries integrated in the train, as is the energy released during the braking process. The hydrogen storage tanks are located above the cabin and the fuel cell is on the roof of the train $[9,10]$. These trains have the capacity to travel approximately $1,000 \mathrm{~km}$ with only one hydrogen tank, which is recharged in 15 minutes [9]. The Coradia iLint runs a $100 \mathrm{~km}$ route between the cities of Cuxhaven, Bremerhaven, Bremervoerde and Buxtehude, in Northern Germany.

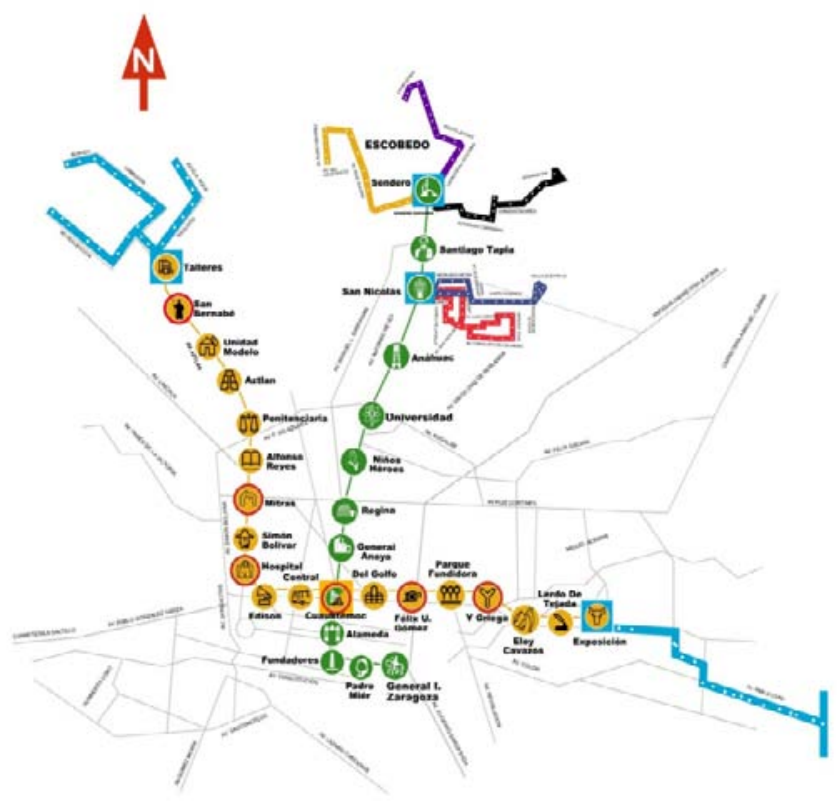

Figure 3. The Collective Transportation System Metrorey network. 


\subsubsection{The Collective Transportation System Metrorey network}

It is a public transportation service which offers a networks of 33 kilometers with 2 lines, and a total of 32 stations [11] (see Figure 3). It is located in Monterrey Nuevo León, Mexico. Since 2006, the Metrorrey Collective Transportation System has an agreement with the company BENLESA (Bioenergía Nuevo León) for the supply and purchase of clean electricity. This company generates clean electrical energy using biogas, which is created from the controlled decomposition of organic waste, which is confined in sanitary landfills on the outskirts of the MAM (Metropolitan Area of Monterrey) [12]. Some of the environmental benefits are the following: it is known as the first sustainable subway for clean energy consumption in the world, it does not pollute, it prevents polluting gases from escaping into the atmosphere, and it is cheaper than conventional electrical energy. Additionally, the annual savings are more than $\$ 738,100$ [12]. It avoids the emission of $68 \mathrm{~m}^{3} / \mathrm{s}$ of Methane and $\mathrm{CO}_{2}$ into the atmosphere which can generate 56 million $\mathrm{kWh}$ per year, enough to supply electricity to a minimum of 15,000 low-income houses in a year.

\subsection{Energy-Harvesting Floor in Urban Public Transportation}

In 2007, two students from the Massachusetts Institute of Technology (MIT) presented a proposal for a tile, which generates energy through pedestrian traffic through the piezoelectric material embedded in the tile. In that same year, the proposal won a sustainable construction competition organized by Holcim, and its proposal was also implemented at the train station in Turin, Italy [13].

In 2008, the East Japan Railway Company's frontier services development laboratory developed a Power-Generating Floor. This was installed as a test in a Tokyo subway station, with the aim of achieving new energy saving facilities for the stations. Energy-harvesting Floor has built-in piezoelectric elements, which generate electricity using the energy of vibrations produced by people who walk on it [14].

At a commercial level, nowadays there are two companies. Firstly, Energy Floor which in 2008 exhibited its product called Sustainable Dance Floor, small modules that have a small generator that generates electricity when the modules flex when stepped on.

Secondly, Pavegen Systems founded in 2009, its tiles are distinguished by their triangular shape and their ability to collect data on pedestrian traffic patterns, the technology used in power generation is through its electromechanical generators.

Equally important, another application proposal for tiles is in vehicular transport routes, having commercial suppliers such as: Innowatech, Genziko Numbers, ODOT and Berkeley and Virginia Tech [13] [15]. In Table 1, the main companies/technologies participating in the manufacturing of energy-harvesting floors are summarized.

Table 1. The main companies participating in the energy-harvesting floors manufacturing

\begin{tabular}{|c|c|c|c|}
\hline $\begin{array}{l}\text { Company/ } \\
\text { technology }\end{array}$ & Product size & Energy & Lifetime (years) \\
\hline Waynergy Floor & $40 \times 40 \mathrm{~cm}$ & $10 \mathrm{~W}$ per-step & 20 \\
\hline Sustainable Energy Floor (SEF) & $75 \times 75 \mathrm{~cm}$ & 5-30 W per-step & 15 \\
\hline \multirow{2}{*}{ Pavegen } & $\begin{array}{l}\text { 1st generation } \\
45 \times 60 \mathrm{~cm}\end{array}$ & 2-4 W per-step & \multirow{2}{*}{20} \\
\hline & $\begin{array}{l}\text { V3 (triangular) } \\
50 \mathrm{~cm} \text { by edge }\end{array}$ & $5 \mathrm{~W}$ per-step & \\
\hline Sound Power & $50 \times 50 \mathrm{~cm}$ & $.05 \mathrm{~W}$ per-step & 20 \\
\hline $\begin{array}{l}\text { Layers of Polyvinylidene polyfluoride (PVDF) } \\
\text { Parquet }\end{array}$ & Layers & $2.1 \mathrm{Ws}$ per-pulse with loads about $70 \mathrm{~kg}$ & 20 \\
\hline Power leap PZT & $24 \times 24$ inch & $0.5 \mathrm{~mW}$ per-step & 20 \\
\hline \multirow{2}{*}{ Hybrid Energy Floor } & $75 \times 75 \mathrm{~cm}$ & $60 \mathrm{kWh}$ per year & \multirow{2}{*}{20} \\
\hline & $1 \times 2 \mathrm{~m}$ & $250 \mathrm{kWh}$ per year & \\
\hline
\end{tabular}




\section{A feasibility study for using energy-harvesting floor in urban public transportation system}

In order to develop a feasibility study for using energy-harvesting floor in urban public transportation system, the energy generated by such kind of floor will be taken into account. Based on the suggestion by Agatón [16], the following items are considered: the energy savings in the installation system, the $\mathrm{CO}_{2}$ emissions avoided, and the return on investment in the installation.

Investment decisions are increasingly problematic, since they imply an approach that integrates social, economic and ecological factors and objectives. For this reason, in this paper, the feasibility study includes the evaluation of economic-environmental and technical aspects.

\subsection{Economic and environmental feasibility}

According to the Mexican Ministry of Environment and Natural Resources and based on international experiences, managing an emissions trading system presents three criteria to measure effectiveness [17] as is shown:

1. Reduction of emissions in relation to economic objectives.

2. Impact on innovation and investment.

3. Profits and the impact on prices of products of participating sectors.

Additionally, some advantages are the follows:

1. Emission reduction taking into account the cost-benefit relation.

2. To be able to face the economic fluctuations with capacity.

3. Encourage technological innovation within companies.

4. Strengthen emission monitoring, reporting and verification systems.

\subsection{Calculating $\mathrm{CO}_{2}$ emissions}

A first important aspect is the demand for conventional energy per year which is developed and presented in Carrillo and Velandia [18] and is illustrated as follows:

$$
\begin{aligned}
& \text { Total demand for conventional energy per day }\left(\frac{\boldsymbol{k W h}}{\boldsymbol{d a y}}\right) \\
& =\text { Total demand for conventional energy }(k W) * \text { hours per day in use } \\
& \text { Total demand for conventional energy per month }\left(\frac{\boldsymbol{k W h}}{\boldsymbol{m o n t h}}\right) \\
& =\frac{\text { Total demand for conventional energy per }(\mathrm{kWh})}{\text { day }} * \frac{30 \text { days }}{1 \text { mont } h}
\end{aligned}
$$

A second important aspect is the $\mathrm{tCO}_{2}$ emissions per year which is formulated as recommended in [18]:

$$
\text { Emissions }\left(\frac{\boldsymbol{t C O}_{2}}{\text { year }}\right)=\text { Total demand for conventional energy } \frac{\mathrm{kWh}}{\text { year }} * \frac{1 \mathrm{MWh}}{1000 \mathrm{kWh}} * 0.2 \frac{\mathrm{tCO}}{\mathrm{MWh}}
$$

\subsection{Energy theoretical costs}

Next, it is necessary to know the annual cost of conventional energy. In this paper, the theoretical cost calculation is given as follows:

$$
\text { Theoretical costs } \frac{\text { pesos }}{\text { day }}=\text { Total demand } \frac{k W h}{d a y} * \operatorname{cost} \frac{\$}{k W h} \text { (one period) }
$$

In order to estimate the emissions avoided, it is necessary to consider the energy produced by the technology implemented as it is demonstrated in the following expressions suggested by [18]:

Energy produced by one unit of energy - harvesting floor

$$
\begin{aligned}
& =1 \text { footstep } * \text { Number of pedestrian } * \text { Energy produced by one unit of the energy } \\
& \text { - harvesting floor }
\end{aligned}
$$

The total number of units of energy-harvesting floor in order to replace the conventional sources with such units is expressed as follow: 


$$
\begin{aligned}
& \text { Total number of units of energy-harvesting floor } \\
& =\frac{\text { Conventional demand } \frac{k W h}{m o n t ~} h}{\text { Energy produced by one unit of energy-harvesting floor } \frac{k W h}{m o n t ~} h}
\end{aligned}
$$

So, the energy savings using energy-harvesting floor is formulated as follows:

$$
\begin{aligned}
& \text { Energy savigs using energy - harvesting floor } \frac{\boldsymbol{k W h}}{\boldsymbol{y e a r}} \\
& =\text { total conventional demand } \frac{\mathrm{kWh}}{y e a r}-\text { total energy - harvesting floor demand } \frac{\mathrm{kWh}}{y e a r}
\end{aligned}
$$

\subsection{Emissions avoided}

The $\mathrm{tCO}_{2}$ emissions avoided are formulated by this equation:

Emissions avoided $\left(\frac{t C \mathrm{O}_{2}}{a \tilde{n} o}\right)$

$$
=\text { energy savigns using energy - harvesting floor } \frac{k W h}{y e a r} * \frac{1 M W h}{1000 k W h} * 0.2 \frac{t C O_{2}}{M W h}
$$

In this paper, the economic savingsfor using energy-harvesting floor calculation is given as follows:

$$
\begin{gathered}
\text { Economic savigns by using energy-harvesting floor } \frac{\text { pesos }}{\text { year }} \\
=\text { Costs by using conventional energy - Costs by using energy - harvesting floor }
\end{gathered}
$$

\subsection{The investment return}

The investment return is given by the following equations:

$$
\begin{gathered}
\text { Investment } \begin{aligned}
\$ & =\text { Sources of energy }- \text { harvesting floor } * \text { Costs of soruces of energy } \\
& - \text { harvesting floor }
\end{aligned} \\
\text { Investment return }=\frac{\text { Investment } \frac{\text { pesos }}{\text { year }}}{\text { Economic savings by using energy }- \text { harvesting floor } \frac{\text { pesos }}{\text { year }}}
\end{gathered}
$$

\subsection{Costs ofcarbon dioxide emission rights}

Based on SENDECO, the annual average price of carbon dioxide emission rights in 2020 is 22.29 euro.

Carbon dioxide emission rigths

$$
=t \mathrm{CO}_{2} \text { eq }\left(\frac{\text { Annual average price of carbon dioxide emission rights }}{t \mathrm{CO}_{2} \mathrm{eq}}\right)
$$

\subsection{Carbon credit}

The carbon credit for reduction of carbon emission is expressed as follows:

Carbon credit for reduction of carbon emission

$$
=t \mathrm{CO}_{2} \text { eq }\left(\frac{\text { Annual average of credit for reduction of carbon emission }}{t \mathrm{CO}_{2} \text { eq }}\right)
$$

The percentage of cost reduction is formulated as follows: 


$$
\% \text { costs reduction }=\frac{\text { Economic savings by using energy }- \text { harvesting floor } \frac{\text { pesos }}{\text { year }}}{\text { Annual cost of conventional energy } \frac{\text { pesos }}{\text { year }}}
$$

\subsection{Technical feasibility}

The investment return will be affected by the number or quantity of technologies to be installed. For using energy-harvesting floors, it is necessary to take into account the possible places of installation, which are recommended to be those that have a high and constant flow of pedestrians [19-21]. In order to identify the sites with the highest flow, the use of simulation is proposed. Therefore, the places with the greatest influx will be found through a density map with the use of the AnyLogic ${ }^{\mathrm{TM}}$ Software.

\section{The case of University subway station of the CTSM}

\subsection{The University subway station}

On the one hand, the University station is the seventh busiest subway station of the 195 total stations, registering an average of 85,743.5 passengers per year in 2019. On the other hand, it is the second busiest subway station on Line 3, accounting for 26,555,624 passengers for the year 2019 [22]. From January to March 2020, the University subway station had a total influx of 5,929,320 passengers [23].

Due to the health emergency (SARS-CoV-2), the passengers flow began to decrease in March 2020, so the station presented an average of 2,144,773 passengers per month.

\subsection{Calculating $\mathrm{CO}_{2}$ emissions}

Based on the period from October to December 2019, operation indicators of Mexico City subway [24], the electricity consumption per passenger transported was $0.4875 \mathrm{kWh}$. That means, in the first two months of 2020 at the University station the energy was as following.

$$
0.4875 \frac{\mathrm{kWh}}{\text { passenger }} * 4289545 \frac{\text { passenger }}{\text { bimester }}=2091153.188 \frac{\mathrm{kWh}}{\text { bimester }}
$$

It is equivalent to produce 1,045. $58 \mathrm{tCO}_{2}$ per bimester. Annually, the production is more than $6,200 \mathrm{tCO}_{2}$.

According to the Federal Electricity Commission (CFE), in April 2020, there was a value of $\$ 1,421 / \mathrm{kWh}$ for energy, which indicates a bimonthly expenditure of $\$ 2,971,528.68 \mathrm{MXN}$ for passengers transported from/to the University station

$$
2091153.188 \frac{\mathrm{kWh}}{\text { bimester }} * 1.421 \frac{\$}{\mathrm{kWh}}(\text { april })=2971528.68 \frac{\text { pesos }}{\text { bimester }}
$$

In this paper, the gran total is: $\$ 17,829,172.08$ per year.

$$
2971528.68 \frac{\text { pesos }}{\text { bimester }} * 6 \frac{\text { bimester }}{\text { year }}=17829172.08 \frac{\text { pesos }}{\text { year }}
$$

\subsection{The agent-based simulation model}

An agent-based simulation model is a computational modeling paradigm whereby a phenomenon is modeled in terms of agents and their interactions and enables us to describe how any agent will behave [25]. The methodology of agent-based simulation encodes the behavior of individual agents in simple rules so that we can observe the results of these agent's interactions [25]. This technique has been used to model and describe the behavior of pedestrian inside the Mexico City subway [26-28].

\subsubsection{The Anylogic ${ }^{\mathrm{TM}}$ software}

The agent-based simulation model is implemented using AnyLogic ${ }^{\mathrm{TM}}$ Personal Learning Edition Software. We used the AnyLogic ${ }^{\mathrm{TM}}$ Pedestrian Library to simulate the pedestrian flow. Such library allows to develop models of building and areas with large numbers of pedestrians such as subway stations [29]. 


\subsubsection{Implementing the agent-based simulation model}

In this case, at the University station, the entrance and exit areas are proposed for the installation of the tiles, which are separated into three sections for the entrance and exit areas respectively. Where 153 tiles were supposed to be placed in the areas with the highest flow of passengers, being 80 for the entrance area and 73 for the exit (Figure 4).

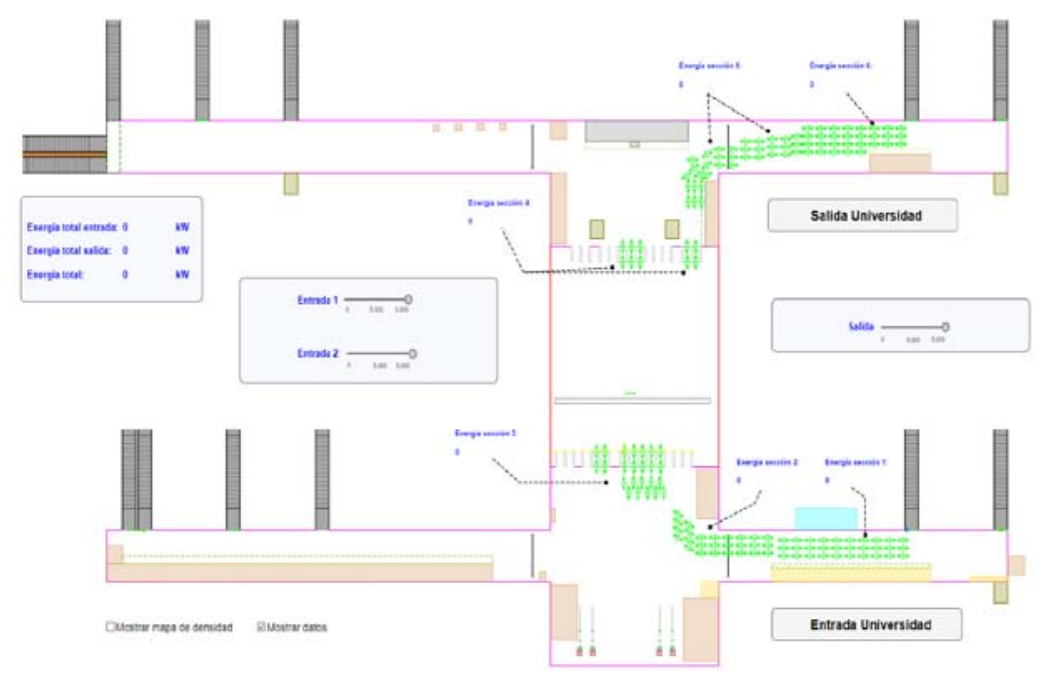

Figure 4. The agent-based simulation model layout: The location of entrances and exits of University station.

\subsubsection{Testing the agent-based simulation model}

The agent-based simulation model was used as a tool for supporting the decision-making process of Mexico City subway authorities about the installation of the tiles in the best areas. The simulation model was executed considering $10 \%$ of passengers in a typical day (Figure 5).
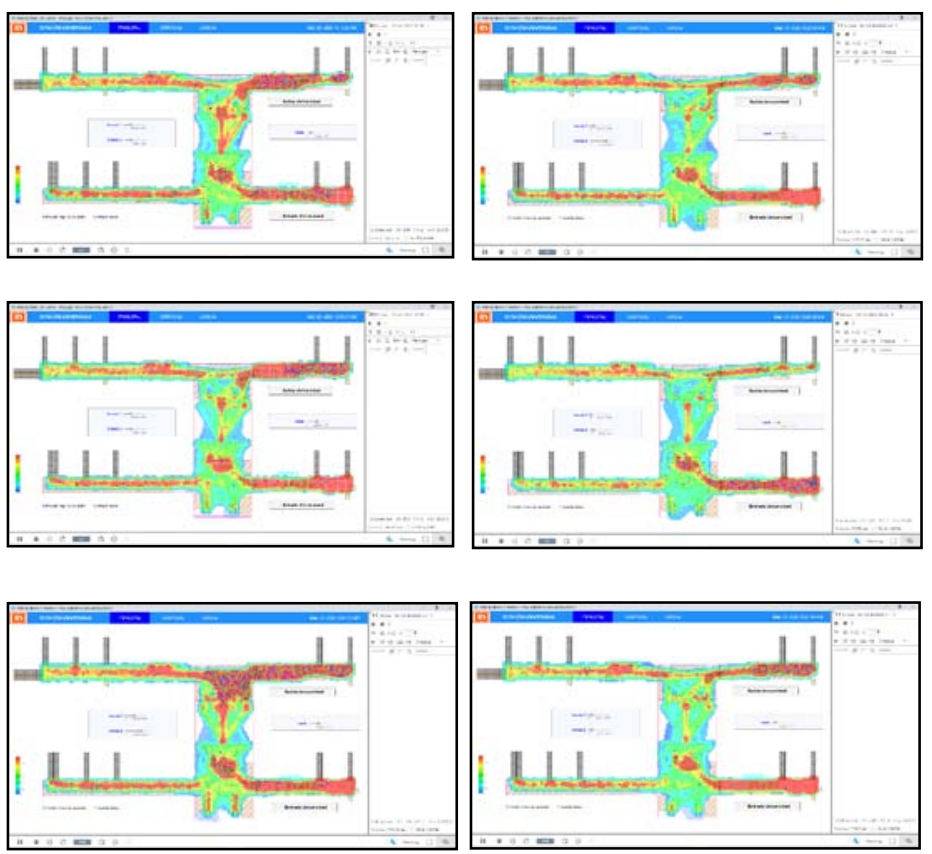

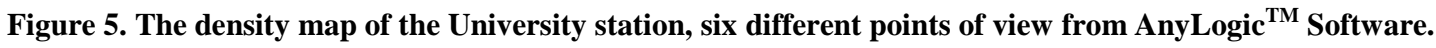




\subsection{Emissions avoided}

In equation (18), we can deduce an amount of 129,995 MW each month, if the passengers pass through the same tile.

$$
1 \text { step } * 2144773\left(\frac{\text { average number of passengers }}{\text { mont } h}\right) * 60.61 \mathrm{~W}=129.995 \mathrm{MW}
$$

In terms of $\mathrm{kWh}$, they were estimated 18,775 kWh monthly.

$$
\left.1 \text { step } * 2144773 \text { ( } \frac{\text { average number of passengers }}{\text { mont } h}\right) * 0.000008755 \mathrm{kWh}=18.7775 \mathrm{kWh}
$$

To quantify the number of tiles required to supply the bimonthly energy demand we have a total of 55,682. In a similar way, it occurs with the number of steps, per passenger, to compensate the energy use.

$$
\begin{aligned}
& \frac{2091153.188 \frac{\mathrm{kWh}}{\text { bimester }}}{(18.7774 * 2) \frac{\mathrm{kWh}}{\text { bimester }}}=55682 \text { tiles } \\
& \frac{0.4875 \frac{\mathrm{kWh}}{\text { passenger on the subway }}}{0.000008755 \frac{\mathrm{kWh}}{\mathrm{step}}}=55682 \text { step by passengers }
\end{aligned}
$$

Although the optimal number of tiles is 55,682, it should be noted that there is uncertainty in the number of steps in the study areas, the entrance and exit zones. Therefore, in the technical field, the proposal of 153 was made, which are better used in the areas studied. With the 153 tiles proposed, they were estimated 19,889,188 MW per month.

$$
1 \text { Paso } * 2144773\left(\frac{\text { average number of passengers }}{\text { mont } h}\right) *(60.61 \mathrm{~W} * 153)=19889.188 \mathrm{MW}
$$

On the other hand, in terms of kWh, 2,872,956 kWh per month were calculated.

$$
1 \text { Paso * } 2144773\left(\frac{\text { average number of passengers }}{\text { mont } h}\right) *(0.000008755 \mathrm{kWh} * 153)=2872.9556 \mathrm{kWh}
$$

In this paper, energy production in one day calculation is given as follows:

$$
\begin{array}{r}
1 \text { Paso } * 71492\left(\frac{\text { average number of passengers }}{\text { day }}\right) *(60.61 \mathrm{~W} * 153)=662.9689 \mathrm{MW} \\
1 \text { Paso } * 71492\left(\frac{\text { average numbe } r \text { of passengers }}{\text { day }}\right) *(0.000008755 \mathrm{kWh} * 153)=95.7546 \mathrm{kWh}
\end{array}
$$

With the help of the agent-based simulation model, an average generation of 125,7985 MW was estimated with an average flow of $10 \%$. The production of 1,257,964 MW per day can be deducted. Unlike the theoretical value of 662,9689 MW per day, the result is mainly due to the arrangement of the tiles. For the value to be similar to the theoretical one, users should step on the 153 tiles and this does not happen because the common path of the users is linear and there are tiles arranged on the sides, of which the user's path may be. So, an approximate of 181,653 kWh per day was calculated.

$$
1257985 \mathrm{~kW} * 0.0001444 \mathrm{hr}=181.653 \mathrm{kWh}
$$

In other words, a production of 10,899,18,204 kWh per two-month period was estimated as follows:

$$
181.653 \mathrm{kWh} * 60 \text { days }=10899.18204 \frac{\mathrm{kWh}}{\text { bimester }}
$$

In consequence, 65,395.09224 kWh are generated annually.

$$
10899.18204 \frac{\mathrm{kWh}}{\text { bimester }} * 6 \frac{\text { bimes ter }}{\text { year }}=65395.09224 \frac{\mathrm{kWh}}{\text { year }}
$$

This situation avoids $5.45 \mathrm{tCO}_{2}$ in a two-month period. Thus, a prevention of $32.7 \mathrm{tCO}_{2}$ per year is inferred.

\subsection{The investment return}

The economic savings with the implementation of tiles is $\$ 15,487.74$ MXN every two months, thus being an annual saving of \$92, 926, $42 \mathrm{MXN}$.

$$
10899.18204 \frac{k W h}{\text { bimester }} * 1.421 \frac{\$}{k W h}(\text { april })=15487.74 \frac{\text { pesos }}{\text { bimester }}
$$




$$
15487.74 \frac{\text { pesos }}{\text { bimester }} * 6 \frac{\text { bimester }}{\text { year }}=92926.44 \frac{\text { pesos }}{\text { year }}
$$

In consequence, the investment of the 153 tiles was $\$ 91,800 \mathrm{MXN}$.

$$
153 \text { tiles } * \$ 600 \text { (tile's cost) }=\$ 91800
$$

This investment could be recovered in 11 months and 25 days.

$$
\frac{\$ 91800 \text { investment }}{92926.44 \frac{\text { pesos }}{\text { year }}}=0.9878 \text { years }
$$

\subsection{Costs of carbon dioxide emission rights}

With the emissions avoided per year, $€ 121,49$ equivalent to $\$ 3,255,68 \mathrm{MXN}$ can be traded.

$$
\begin{gathered}
5.45 \mathrm{tCO}_{2 \text { eq }} *\left(\frac{22.29 € .}{t \mathrm{CO}_{2 \text { eq }}}\right)=121.4895 € \text { Carbon dioxide emission rights. } \\
121.4895 € *\left(\frac{26.80 \mathrm{MXN}}{1 €}\right)=3255.6774 \mathrm{MXN}
\end{gathered}
$$

\subsection{Carbon credit}

While for carbon credits only $€ 1.91$ which is similar to $\$ 51.12 \mathrm{MXN}$.

$$
\begin{gathered}
5.45 \mathrm{tCO}_{2 \text { eq }} *\left(\frac{0.35 €}{t C O_{2 e q}}\right)=1.9075 € \\
1.9075 € *\left(\frac{26.80 \mathrm{MXN}}{1 €}\right)=51.121 \mathrm{MXN}
\end{gathered}
$$

When making the currency exchange with reference to the Banco de México website, the euro $€$ currency is valued at $\$ 26.80 \mathrm{MXN}$. Therefore, a $€ 1=\$ 26.80 \mathrm{MXN}$.

\section{Conclusion}

The principal purpose of this paper was to develop a feasibility study for using energy-harvesting floor in urban public transportation system and to apply it to CTSM stations. The study included technical and economic and environmental feasibility.

On the one hand, the technical feasibility has the main advantage is the versatility of the tiles within urban areas, which are increasingly limited in space. Also, tiles are independent of meteorological conditions, for operation only requires the steps of a flow of persons. It is a decentralized alternative source of energy, which can be in the form of distributed generation. Additionally, the tiles work as a low power generator.

Tiles present some disadvantage as well as other renewable energy sources, it is the requirement of energy storage sources.

On the other hand, in respect to the economic and environmental feasibility, it is important to note that the investment is recovered in approximately one year. However, installation costs were not considered, because they are unknown. In terms of avoided emissions, only 5.45 tCO2 per year are prevented. Consequently, emission rights and carbon credits are small values, so trading is not viable. In conclusion it is feasible to install tiles into the CTSM stations in order to save costs.

\section{Acknowledgements}

This work was supported by Cátedra Especial “Carlos Ramírez Ulloa”.

\section{References}

[1] The World Bank. (2018). Energy. http://www.bancomundial.org/en/topic/energy/overview.

[2] Estrada, C. A. and Islas, J. M. (2013). Energía. Academia Mexicana de Ciencias, Consejo Nacional de Ciencia y Tecnología y Dirección General de Divulgación de Ciencia UNAM, Ciudad de México.

[3] Agenda Ciudadana en Iberoamérica. (2017). Energía. https: //agendaiberoamericana.org/mexico/index.php/temas/energia.

[4] Cortés, S. and Arango, A. (2017). Energías renovables en Colombia: una aproximación desde la economía. Revista Ciencias Estratégicas, 25(38): 375-390.

[5] Gobierno de la CDMX. (n.d.). Cambio climático lo que debes saber. https://www.sedema.cdmx.gob.mx/storage/ 
app/media/cambioclimatico.pdf.

[6] Sistema de Transporte Colectivo Metro. (2017). Proyecto de prestación de servicios a largo plazo para el diseño, construcción, puesta en marcha, operación y mantenimiento de una planta de termovalorización para producción de energía eléctrica, para el Sistema de Transporte Colectivo, Metro. https://metro.cdmx.gob.mx/storage/app/media/Informacion\% 20L12/Manifestaciones\%20escritas\%20de\%20Asuntos\%20Relevantes/PLANTA\%20DE\%20TERMOVALORIZACION.pdf.

[7] United Nations. (n.d.). Sustainable Development Goals. https://www.un.org/sustainabledevelopment/.

[8] Das Eisenbahn-Bundesamt. (2019). Service. https://www.eba.bund.de/SharedDocs/Pressemitteilungen/DE/2018/04_2018_ Erster_Wasserstoffzug_erhaelt_Zulassung.html.

[9] BCC. (2019). Así funciona el tren de hidrógeno que inició operaciones en Alemania, el primero en entrar en servicio comercial en el mundo. https://www.bbc.com/mundo/noticias-45552735.

[10] ALSTOM. (2019). Coradia Ilint Wasserstoffzuf erhält Zulassung für den Fahrgasteinsatz im deutschen Schienenverkehrsnetz. https://www.alstom.com/de/press-releases-news/2018/7/coradia-ilint-wasserstoffzug-erhalt-zulassung-fur-den-fahrgasteinsatz-i m-deutschen-schienenverkehrsnetz.

[11] Gobierno de Nuevo León. (2019). Metro. http://www.nl.gob.mx/servicios/metro.

[12] Asociación Mexicana de Ferrocarriles. (2014). STC Metrorrey Pasado Presente y Futuro. https://amf.org.mx/pdfs/premetrorey. pdf.

[13] Tamayo, D. A. and Cardozo, N. K. (2017). El uso de piezoeléctricos para la generación de energía sostenible como proyecto piloto en un perfil vial de Bogotá. Bachelor’s Thesis, Universidad Católica de Colombia, Bogotá.

[14] East Japan Railway Company. (2008). Demonstration Experiment of the "Power-Generating Floor" at Tokyo Station. https://www.jreast.co.jp/e/development/press/20080111.pdf.

[15] Kour, R. and Charif, A. (2016). Piezoelectric Roads: Energy Harvesting Method Using Piezoelectric Technology. Innovative Energy \& Research, 5: 132.

[16] Agatón, F. J. (2014). Análisis de la factibilidad económica y ambiental de utilizar baldosas piezoeléctricas en el campus de la universidad militar nueva Granada (UMNG). https://repository.unimilitar.edu.co/handle/10654/12025.

[17] Secretaría de Medio Ambiente y Recursos Naturales. (2019). Programa de prueba del sistema de comercio de emisiones. https://www.gob.mx/cms/uploads/attachment/file/505785/PREGUNTAS_FRECUENTES_SCE.pdf.

[18] Carrillo, S. A. and Velandia, R. A. (2016). Propuesta para la implementación de una alternativa que permita mejorar la eficiencia energética en el edificio Rafael Arboleda Universidad Javeriana, Bogotá. Magister'sThesis, Facultad de Estudios Rurales y Ambientales, Bogotá.

[19] Kyung-Bum, K., Jae, C., Hamid, J., Jung, A., Seong, H., Sang, W., and Tae, S. (2018). Optimized composite piezoelectric energy harvesting floor tile for smart home energy management. Energy Conversion and Management, 171: 31-37.

[20] Furio, C., Alessandro, S., Aldo, M., Marinela, M., Giuseppe, R., and Alessio, C. (2018). Analysis of the energy extracted by a harvester based on a piezoelectric tile. Current Applied Physics, 18: 905-911.

[21] L. Morras, L. (2019). Pisadas que no dejan huella. ¿Es viable producir energía al andar? http://oa.upm.es/53978/1/ TFG_Morras_Barrio_Lucia.pdf.

[22] Sistema de Transporte Colectivo Metro de la Ciudad de México. (2020). Afluencia de estación por línea 2019. https://metro.cdmx.gob.mx/afluencia-de-estacion-por-linea-2019.

[23] Gobierno de la Ciudad de México. (2020). Afluencia diaria del Metro CDMX. https://datos.cdmx.gob.mx/explore/dataset/afluencia-diaria-del-metro-cdmx/table/?sort=-fecha.

[24] Sistema de Transporte Colectivo Metro. (2020). Indicadores de operación 2019. https://metro.cdmx.gob.mx/indicadores-2019.

[25] Wilensky, U., and Rand, W. (2015). An introduction to agent-based modeling. Modeling natural, social, and engineered complex systems with NetLogo. The MIT Press. Cambridge, Massachusetts. England.

[26] Vera Morales, A., and Huerta Barrientos, A. (2016). Simulation optimization of pedestrian evacuation in Mexican subway: the case of Pino Suarez station. In Proceedings of the European Modeling and Simulation Symposium, Bruzzone, Jiménez, Longo, Louca and Zhang (Eds.), pp. 175-182.

[27] Bautista-Martínez, H. O. I., Huerta Barrientos, A., and Portillo-Villasana, G. J. (2016). Minimizing the impact of escalator failures in metro Tacubaya subway station on user's mobility. In Proceedings of the European Modeling and Simulation Symposium, Bruzzone, Jiménez, Longo, Louca and Zhang (Eds.), pp. 224-230.

[28] Avila Callejas, L. P., and Huerta Barrientos, A. (2019). Reducing Congestion of Transfer Subway Station During Peak Hours: the Case of Study Guerrero Station. In Advances in Analysis Decision-Making for Complex and Uncertain Systems by Józefczyk, J. and Lasker, G. E. International Institute for Advances Studies in Systems Research and Cybernetics.

[29] Grigoryev, I. (2015). Anylogic 7 in three days. A quick course in simulation modeling. 